ISSN: 2362-1303 (Paper) | eISSN: 2362-1311(Online)

JOURNAL OF ADVANCED ACADEMIC RESEARCH (JAAR)

January 2015

\title{
Researcher Observational Analysis of the Role of Educational Facilities on Students' Achievement
}

\section{Bijaya Nepal $^{1}$ \& Prof. Dr. Ramkrishna Maharjan²}

${ }^{1} \mathrm{PhD}$ Scholar, Mewar University, Rajasthan, India

${ }^{2}$ Professors, Tribhuvan University, Kathmandu, Nepal

Corresponding Author

Bijaya Nepal

Email: bijaya_nepal77@yahoo.com

\section{Abstract}

This study was undertaken to analyse the researcher's observation on different five variables: school's library, e-library, science laboratory, availability of computer laboratory and its management. These educational facilities effect on the learning process and the achievement of the students'. The main objective of this study was to analyse the role of schools' educational facilities on students' achievement on community-based school and institutional schools of Central Development Region of Nepal. The data presented in this paper were collected to know the measurement of availability of educational facilities and students' achievement from the selected schools for the research. This study was conducted from January to July 2014. During this time, observation checklist was designed to obtain descriptive results using cross tabulation and percentage; and multi-stage sampling methods were applied. The sample size was taken proportionately from 3,125 numbers of Secondary and Higher Secondary schools. The selected districts were Sindhupalchok, Kavre, Makwanpur, Kathmandu and Chitwan. From the universe, 32(1.02 percent) schools were taken by using proportionate stratified random sampling. The value of data Cronbach's Alpha is 0.86 within 36 variables. Analysis of data was done by using the SPSS version 20. Chi-square test was applied to analyze the data. There was significance association $(p=.000)$ between community and institutional schools students' achievement test min score of science and computer subjects and significance association $(p=.010)$ among ecological region (Mountain, Hill, Valley and Terai) students achievement test min score of five core subjects has been found which means that the availability and management of educational facilities and achievement in most of the private schools are better than governmental one.

Keywords: Educational Facilities, Observational Analysis and Students' Achievement 
ISSN: 2362-1303 (Paper) | eISSN: 2362-1311(Online)

JOURNAL OF ADVANCED ACADEMIC RESEARCH (JAAR)

January 2015

\section{Introduction}

Schools exist for the purpose of teaching and learning. Educational facilities are provided for this purpose. They are the material and resources provided to the teachers and the students to optimize their productivity in teaching and learning process. The realization that the transfer of knowledge does not only take place in the four walls of the classroom, but it goes beyond it. So, it does not limit within the teacher and the students, rather the learning takes place through discovery, exploration and interaction with the internal. External environment has necessitated the creative and innovative development of teaching and learning facilities that reflect these changes (Asiabaka, 2008). Useful types of educational facilities to be contacted by the planners and the school management team are acoustical design engineering, audio visual, sciences laboratory, building design, interior design, computer laboratory, lighting design, management consulting, project planning, site planning, technical equipment specialization, and urban planning(Propst, 1972).

Firstly, the government should provide necessary facilities for the schools. Secondly, School Management Committee can manage all type of necessary facilities and thirdly, the head of the school should ensure optimal implementation of these facilities. Policies and Programmes of the Government of Nepal for fiscal year 2071-72 (2014-15), In order to promote quality education of school, "one school; one library and e-library, and one school; one science laboratory" programmes will be launched gradually in secondary schools. Technological gap will be reduced through education system based on information technology (GoN, 2014, p. 9).

There are basically two types of financial assistance by the government to provide necessary assistance to public schools in Nepal. The first is earmarked grants; this includes teachers' salary, textbooks, scholarship etc. The second type involves block grants; which includes the school's cost of administrative expenses, expenditures related to infrastructure development and educational materials. Out of the total number of grants that a school receives in an academic year, around 80 percent goes to teacher's salary and only 20 percent to construction and educational material support (Thapa, 2011, p. 25).

E-library is an education-focused digital library containing full-text documents, books, images, videos, audio files, and interactive educational software that can be accessed through an intranet or on the Internet. It was started in Nepal from 2008 with the aims to improve children's' Nepal reading skills and develop a reading culture in schools by giving them free and open access to age-appropriate reading materials and to enable students to do research projects and promote habit of independent inquiry (OLE Nepal, 2015 ). The Ministry of Education of the Government of Nepal is beginning to show an interest in enhancing the quality of education in Nepali schools through the use of Information and Communication technology. The vision is to provide an elibrary in every high school in Nepal. About one million US dollars have been allocated for the current fiscal year to start a pilot programme(Naresh \& Paul, 2011, pp. 7-8). 
ISSN: 2362-1303 (Paper) | eISSN: 2362-1311(Online)

JOURNAL OF ADVANCED ACADEMIC RESEARCH (JAAR)

Nepal's National Planning Commission Three Year Interim Plan (2007/8-2009/10) includes the following statement: 'Libraries will gradually be established in community schools. Programs will be implemented to encourage local bodies and organizations to open and run libraries in different educational institutes in the backward regions.' This is a step in the right direction, but much robust action is required. Sadly, there is little evidence to show that even this programme has been implemented (Naresh \& Paul, 2011, pp. 7-8).

Computer Laboratory; the school has large well-equipped computer labs for the use of junior and senior students set up by highly qualified professionals. The computer courses have been made compulsory for students of classes III to secondary level. It is powered by Pentium, multimedia, the necessary hardware and software, to reinforce the students' abilities with required computing knowledge and skills.

Educational facilities are those things that enable the teacher to take out their work well and also help the students to learn easily. Educational facilities are vital tools in the teaching and learning process, therefore adequate provision, management and implementation these facilities (Lawanson \& Gede, 2011, p. 50).

Library is a counterpart of a school physical infrastructure. It plays a vital role in the learning process of the school. The library is an essential component of a good school (Deepak Raj \& Tapash, 2013). The library room should be located in such a place where students are not getting disturbed by noise (GoN, 2010).It is a useful means of storing communicable knowledge and nobody can do much without it. A library is a repository of books and should have textbooks, workbooks, reference books, fiction, and non-fiction books at various reading levels, reference books oil special topics and interests and related pamphlets, clippings, pictures, maps, charts, periodicals, etc. are placed in proper shelf (Tribhuvan University, 2002).

Laboratory is an essential part of a school. This is the place where experiments are performed and hypothesis are tested and verified. At +2 stages, a school needs biology, physics, chemistry, a computer laboratory (OECD , 2013c, p. 5). Mere knowledge would not be sufficient for building the required competence in specific content area. If theory is supported by practices, clarity could be maintained as well as psychomotor skills could be developed (OECD , 2013b).

The most fundamental problem in facilities provision is lack of policy guidelines for infrastructural development in schools. In some schools, there are inadequate classrooms, staff offices, laboratories and workshops, libraries, study areas while in some, these facilities are adequately provided. This situation arises as the Nepal Governments have failed to establish policy directives on minimum standards in relation to educational facilities (Timsina, 2008). While some classes hold under trees and students are exposed to harsh weather conditions, others hold in air conditioned classrooms. While some others have well equipped laboratories, workshops, libraries and other facilities for effective teaching and learning, others have none, 
ISSN: 2362-1303 (Paper) | eISSN: 2362-1311(Online)

JOURNAL OF ADVANCED ACADEMIC RESEARCH (JAAR)

and where they exist, such facilities are poorly equipped. It therefore becomes imperative that the different levels of government should address the issue of development and implementation of minimum standards for facilities development and management.

This study focuses on to examine the differences between community and institutional school's infrastructure by using researcher's observation about the facilities arranged by the school. So, data were collected from the schools to measure the condition of school infrastructure and students' achievement. On the basis of observation checklist survey conducted in June 2014, the situation of existing essential and basic school infrastructure availability and management. The main objective of this study was to analyse the role of schools infrastructure on students' achievement of community and institutional schools of central development regions of Nepal. This study was limited on researcher observational analysis regarding essential infrastructure and technology (School building, computer laboratory, science laboratory, library and e-library) in secondary and higher secondary school and their students' two subjects' achievement test means score of central development region of Nepal.

\section{Management of Educational Facilities}

Specific educational facilities requirement of community and institution schools in terms of type quantity and quality needs to be properly assessed to provide the operational guide for facilities provision. A comprehensive diagnostic inventory survey of the existing stock of educational facilities in the community or institution should be done. This will provide the educational map or the distributional network of the existing educational facilities needed in the development of the facilities master plan. The government should make sure that all the educational facilities such as educational, game facilities, school building and general-purpose facilities should be provided (Lawanson \& Gede, 2011).

Educational facilities management is a systematic process of rationalizing the provision, use and maintenance of these facilities within an educational institution to ensure their optimal utilization and achievement of educational objectives both in the immediate and in the future given the available resources. In other words, it a process that involves rationally: Determining which facilities are required to achieve school goals; Providing such facilities most advantageously in terms of resource use, Monitoring to ensure optimal use of educational facilities so provided, Maintaining the facilities regularly to ensure their longevity and Reviewing the provision of these facilities to ensure that it continues to meet both the changing educational needs in the advantageous manner The activities that come under the umbrella of educational facilities management or educational facilities planning and administration are sequentially linked. Consequently, these activities will be recognized as stages in a chain of activities (Laboratories, 1955; Asiabaka, 2008 and Lawanson \& Gede, 2011). The following are stages in sequential order: 1) recognition of learning needs, 2) list of evaluation, 3) facilities utilization analysis, 4) establishment of educational facilities master plan, 5) site selection and acquisition, 6) 
ISSN: 2362-1303 (Paper) | eISSN: 2362-1311(Online)

JOURNAL OF ADVANCED ACADEMIC RESEARCH (JAAR)

January 2015

preparation of educational specifications and educational project design (Lawanson \& Gede, 2011, pp. 50-53).

\section{$\underline{\text { Theoretical Prospective }}$}

According to CarolCash, 1993, the Cash model, shown in Figure 1 below; the condition of the school's educational facilities is indirectly related to student achievement because of its effect on the attitudes of students. Well-maintained school educational facilities will send a message to management that education is important. Conversely, poorly maintained school educational facilities will send the message that education is not important and a negative attitude will be passed on to the students (Linda Lemasters , 1997), (Lanham's ,1999) and (Al-Enezi , 2002);(O’Sullivan, 2006).

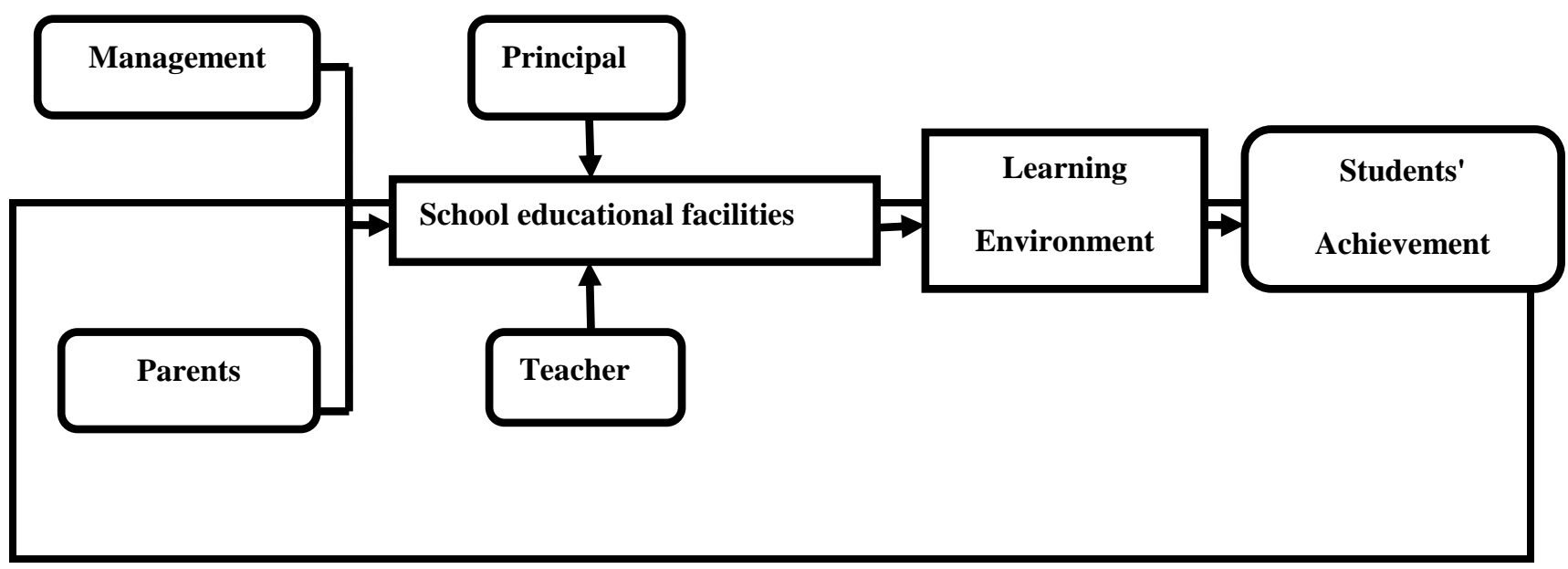

Figure: 1 Role of school educational facilities

\section{Impact of Physical Facilities on Student's Achievement}

According to Lyons (2002), learning is a complex activity that puts students' motivation and physical condition to the test. It has been a long-held assumption that curriculum and teaching are the only major parameters that have an impact on learning. However, it is becoming more apparent that the physical conditions in schools indeed influence student achievement. Pearls (2008) observe that design features and components of school buildings have been proven to have a measurable influence upon student learning. Among the influential features and components are those impacting temperature, lighting, acoustics and age. Researchers have found a negative impact upon student performance in buildings where deficiencies in any of these features exist. In addition, overcrowded school buildings and classrooms have been found to be a negative influence upon the students' performance. Particular building feature such as air conditioning, lighting, or presence of windows to serve as variables with which to compare students' achievement. The overall impact of a school building on students can be either positive or negative, depending upon the condition of the building. In cases where students attend school in substandard buildings they are handicapped in their academic achievement. Correlation 
ISSN: 2362-1303 (Paper) | eISSN: 2362-1311(Online)

JOURNAL OF ADVANCED ACADEMIC RESEARCH (JAAR)

January 2015

studies show a strong positive relationship between overall building conditions and student achievement. Studies by Pearls (2008) regarding the number of students in schools as compared with its capacity found out that overcrowded conditions have a negative influence upon students and teachers.

In summary, the reviewed study indicates the impact of use of instructional materials and resource utilization on student achievement. While there is abundant research on impact of these parameters in education, there is none with samples that include Central Nepal. Understanding the impact of instructional materials in education is important for all education stakeholders in this development region in order to provide appropriate resources for effective and improved academic achievement. Central Nepal has not had any documented assessments of principals and teachers perception of resource utilization in education. The proposition examined in this study was that at least part of the explanation for the link between school resource utilization, quality and education outcomes is the mediating influence of instructional facilities.

\section{Method}

Descriptive and analytical research design was used and cross-sectional data were collected to analyse comparison between status of the schools ' infrastructure management and students' achievement test result of community and institutional schools' of Central Nepal. This study was related to researcher observation analysis. So, only observation tool was used for the research.

The research was done on the basis of multi-stage sampling method. The targeted area of the study was Nepal, where the research was accomplished. In the first stage cluster, random sampling method was used, where the field i.e. Nepal was divided into five development regions. One of them was Central Development Region (CDR) was taken as a single cluster.

In second stage, the single cluster is divided into four sub-clusters (Mountain, Hill, Valley and Terai) on the basis of ecological belt. Furthermore, five districts were selected as a study area among nineteen cluster i.e. nineteen districts of four ecological belts.

In third stage, the proportionate stratified random sampling method was used to select target schools from both urban and rural areas': community and institutional in secondary and higher secondary schools' of five districts. So, the secondary and higher secondary schools were taken as universe. The sample size was taken as proportionately among number of 3125 (1893 Secondary and 1232 higher secondary schools) (GoN, 2012, p. 79). The selected districts were Sindhupalchok, Kavre, Makwanpur, Kathmandu and Chitawan and 32 (1.02 percent) schools were taken from total universe by using proportionate stratified random sampling. 
ISSN: 2362-1303 (Paper) | eISSN: 2362-1311(Online)

JOURNAL OF ADVANCED ACADEMIC RESEARCH (JAAR)

January 2015

\section{Instrumentation, Data Collection and Analysis}

Observation check list and rating scale for informal discussion with principal were used as data collection tools. Observation check list and rating scale were developed by researcher. It consisted of five questions along with some educational facilities information required to be filled in by the respondents. Among these questions, four were in the form of checklist; mostly having answers liked scale the researcher was fill-up suitable information which is chick list show.

The subject matters were about school educational facilities; library, e-library, science laboratory, computer laboratory and students achievement test. The reliability and validity of the instrument was maintained by seeking opinion of the subject experts, pilot study, and Cronbach's Alpha test. The value of data Cronbach's Alpha is .085 within 36 indicators. Analysis of data was done by using the SPSS 20. Frequency table, cross tabulation, Chi-square test were applied to analyse the data.

\section{Result and Discussion}

This chapter presents research findings, researcher interpretation and discussion. In this study, 32 schools were taken as sample for analysis of availability of instructional facility and students' achievement. Schools were chosen from four ecological regions; among them: 3(9.4 percent) schools from mountain region, 9(28.1 percent) schools from hill, 13(40.6 percent) from schools from valley and 7(21.9 percent) schools from Terai. The study investigated the role of educational facilities availability and utilization in instructional programmes in secondary and higher secondary schools. Analysis of subject matters in checklist form, two types of issues were included. One type was 'checklist' having answers in; 'Not available, Very Unsatisfactory, Unsatisfactory, Satisfactory, and Very Satisfactory' and the other was 'check list with grouping form'.

The research looked at factors such as;

- The adequacy of reference book in library in community and institutional schools in Central Nepal.

- The sufficiency of e-library and their utilization in community and institutional schools in Central Nepal.

- The availability of computer in computer laboratory and the extent of their utilization in community and institutional schools in Central Nepal.

- The adequacy of science laboratory and their utilization in community and institutional schools in Central Nepal.

- Level of ability in two subjects (computer and science) of students' in community and institutional schools in Central Nepal. 
ISSN: 2362-1303 (Paper) | eISSN: 2362-1311(Online)

JOURNAL OF ADVANCED ACADEMIC RESEARCH (JAAR)

The research findings are presented using descriptive statistics.

Researcher observation data have been collected to analyze comparison between availability of instructional facility and students' achievement test of community and institutional School of Nepal which was on the basis of observation check list survey conducted in June 2014and discussed as follows:

Table: 1 Condition of library

\begin{tabular}{|c|c|c|c|c|c|c|c|c|c|}
\hline \multirow{3}{*}{\multicolumn{2}{|c|}{ Condition of library }} & \multirow{2}{*}{\multicolumn{2}{|c|}{$\begin{array}{l}\text { Types of schools* } \\
\text { Communi Institution }\end{array}$}} & \multicolumn{4}{|c|}{ Ecological region** } & \multirow{3}{*}{ Total } & \multirow{3}{*}{$\begin{array}{l}\text { Cumulativ } \\
\text { e Percent }\end{array}$} \\
\hline & & & & \multirow{2}{*}{\multicolumn{2}{|c|}{$\begin{array}{l}\text { Mounta Hill } \\
\text { in }\end{array}$}} & \multirow{2}{*}{\multicolumn{2}{|c|}{ Valley Terai }} & & \\
\hline & & ty & al & & & & & & \\
\hline \multirow{2}{*}{ Not available } & Count & 4 & 4 & 1 & 4 & 2 & 1 & 8 & \multirow{2}{*}{25.0} \\
\hline & Total $\%$ & 12.5 & 12.5 & 3.1 & 12.5 & 6.2 & 3.1 & 25.0 & \\
\hline Very & Count & 4 & 4 & 1 & 0 & 6 & 1 & 8 & \multirow{2}{*}{50.0} \\
\hline Unsatisfactory $^{1}$ & Total $\%$ & 12.5 & 12.5 & 3.1 & 0.0 & 18.8 & 3.1 & 25.0 & \\
\hline \multirow{2}{*}{ Unsatisfactory $^{2}$} & Count & 0 & 1 & 0 & 0 & 1 & 0 & 1 & \multirow{2}{*}{53.1} \\
\hline & Total $\%$ & 0.0 & 3.1 & 0.0 & 0.0 & 3.1 & 0.0 & 3.1 & \\
\hline \multirow{2}{*}{ Satisfactory $^{3}$} & Count & 4 & 1 & 1 & 1 & 1 & 2 & 5 & \multirow{2}{*}{68.8} \\
\hline & Total \% & 12.5 & 3.1 & 3.1 & 3.1 & 3.1 & 6.2 & 15.6 & \\
\hline \multirow{2}{*}{ Very Satisfactory } & Count & 4 & 6 & 0 & 4 & 3 & 3 & 10 & \multirow{2}{*}{100.0} \\
\hline & Total \% & 12.5 & 18.8 & 0.0 & 12.5 & 9.4 & 9.4 & 31.2 & \\
\hline \multirow{2}{*}{ Total } & Count & 16 & 16 & 3 & 9 & 13 & 7 & 32 & \multirow{2}{*}{100.0} \\
\hline & Total \% & 50.0 & 50.0 & 9.4 & 28.1 & 40.6 & 21.9 & 100.0 & \\
\hline
\end{tabular}

Sources: Field survey, June 2014

$*$ No significant association $P=0.525$ (2-sided), $* *$ No significant association $P=0.391(2$-sided)

Above table 1 explores the status of school library with respect to school locality i.e. mountain, hill, valley and Terai. It is evident from the chi-square results that there is no significant difference among ecological regionsand types of schools with respect to availability of library facility sufficiency. Against all variables no significant difference were found. School must have provision of appropriate library facilities and sufficiency books and references books (GoN, 2010). But data shows that more than 50 percent schools' library facility is very poor condition.

\footnotetext{
${ }^{1}$ Facility is available butfewer than 1500 books are available and library room is not properly managed.

${ }^{2}$ Facility is available but 1501 to 2000 books are available and library room is not properly managed.

${ }^{3}$ Facility is available and 2001 to 2500 books are available and library room is properly managed.

${ }^{4}$ More than 2500 books are available and library room is properly managed.
} 
ISSN: 2362-1303 (Paper) | eISSN: 2362-1311(Online)

JOURNAL OF ADVANCED ACADEMIC RESEARCH (JAAR)

January 2015

Table: 2 Condition of e-library

\begin{tabular}{|c|c|c|c|c|c|c|c|c|c|}
\hline \multicolumn{2}{|c|}{ Availability of e-library } & \multirow{2}{*}{\multicolumn{2}{|c|}{\begin{tabular}{|l|} 
Types of schools* \\
CommunityInstitutional
\end{tabular}}} & \multicolumn{4}{|c|}{ Ecological region $* *$} & \multirow{2}{*}{\multicolumn{2}{|c|}{$\mid$\begin{tabular}{|l} 
Total \\
$\begin{array}{l}\text { Cumulative } \\
\text { Percent }\end{array}$ \\
\end{tabular}}} \\
\hline & & & & \multicolumn{2}{|c|}{ Mountain|Hill } & \multicolumn{2}{|c|}{ Valley Terai } & & \\
\hline \multirow[t]{2}{*}{ Not available } & Count & 13 & 7 & 2 & 5 & 8 & 5 & 20 & \multirow{2}{*}{62.5} \\
\hline & Total \% & 40.6 & 21.9 & 6.2 & 15.6 & 25.0 & 15.6 & 62.5 & \\
\hline Very & Count & 2 & 1 & 1 & 1 & 1 & 0 & 3 & \multirow{2}{*}{71.9} \\
\hline Unsatisfactory ${ }^{5}$ & $\sqrt[5]{\text { Total \% }}$ & 6.2 & 3.1 & 3.1 & 3.1 & 3.1 & 0.0 & 9.4 & \\
\hline \multirow{2}{*}{ Unsatisfactory $^{6}$} & 6 Count & 0 & 2 & 0 & 0 & 1 & 1 & 2 & \multirow{2}{*}{78.1} \\
\hline & Total \% & 0.0 & 6.2 & 0.0 & 0.0 & 3.1 & 3.1 & 6.2 & \\
\hline \multirow{2}{*}{ Satisfactory $^{7}$} & Count & 1 & 5 & 0 & 3 & 2 & 1 & 6 & \multirow{2}{*}{96.9} \\
\hline & Total \% & 3.1 & 15.6 & 0.0 & 9.4 & 6.2 & 3.1 & 18.8 & \\
\hline \multirow{2}{*}{$\begin{array}{l}\text { Very } \\
\text { Satisfactory }^{8}\end{array}$} & Count & 0 & 1 & 0 & 0 & 1 & 0 & 1 & \multirow{2}{*}{100.0} \\
\hline & Total \% & 0.0 & 3.1 & 0.0 & 0.0 & 3.1 & 0.0 & 3.1 & \\
\hline \multirow{2}{*}{ Total } & Count & 16 & 16 & 3 & 9 & 13 & 7 & 32 & \multirow{2}{*}{100.0} \\
\hline & Total \% & 50.0 & 50.0 & 9.4 & 28.1 & 40.6 & 21.9 & 100.0 & \\
\hline
\end{tabular}

Sources: Field survey, June 2014

$*$ No significant association $P=0.099$ (2-sided), **No significant association $P=0.827$ (2-sided)

The above table shows that no signification associationhas been found between community and institutional schools and ecological wise schools. The data show that more than 70 percent schools' e-library facility availability is very poor condition and more than 40 community schools have not available modern educational facilities i.e. e-library. The learning environment in school is considered to be primary factor for enhancing the effectiveness of modern technology aspect (Daggett, 2008). In the same manner, the provision of educational material also helps the teachers to make the students learn the specific objectives of the course book (GoN, 2010). Information communication technology also include among others soft ware's (OECD , 2013c). The application of the software requires that the school principal should be exposed to necessary in-service training to enable them make maximum use of the software(Asiabaka, The Need for Effective Facility Management in Schools in Nigeria, 2008). Modern educational equipment shall be provided to each class as required (MOLJI, 2009).

Table: 3 Condition of science laboratory

\footnotetext{
${ }^{5}$ E-library is available but not properly managed and students are not extent of their utilization.

${ }^{6}$ E-library is available but students are not extent of their utilization.

${ }^{7}$ E-library is available and properly managed this.

${ }^{8}$ E-library is properly managed and students and teachers are extent of their utilization.
} 
ISSN: 2362-1303 (Paper) | eISSN: 2362-1311(Online)

JOURNAL OF ADVANCED ACADEMIC RESEARCH (JAAR)

\begin{tabular}{|c|c|c|c|c|c|c|c|c|c|}
\hline $\begin{array}{l}\text { Condition of } \\
\text { laboratory }\end{array}$ & Science & \begin{tabular}{|l|} 
Type \\
Com
\end{tabular} & $\begin{array}{l}\text { hools* } \\
\text { Institutional }\end{array}$ & \begin{tabular}{|l} 
Eco \\
Mou
\end{tabular} & $\frac{\text { al re }}{\mathrm{h} \text { Hill }}$ & $\begin{array}{l}\text { gion: } \\
\text { Vall }\end{array}$ & Terai & Total & $\begin{array}{l}\text { Cumulative } \\
\text { Percent }\end{array}$ \\
\hline \multirow[b]{2}{*}{ Not available } & Count & 3 & 5 & 0 & 3 & 4 & 1 & 8 & \multirow[b]{2}{*}{25.0} \\
\hline & $\begin{array}{|ll|}\% & \text { of } \\
\text { Total } & \\
\end{array}$ & 9.4 & 15.6 & 0.0 & 9.4 & 12.5 & 3.1 & 25.0 & \\
\hline \multirow{2}{*}{$\begin{array}{l}\text { Minimum } \\
\text { requirement }\end{array}$} & Count & 10 & 6 & 2 & 3 & 7 & 4 & 16 & \multirow[b]{2}{*}{75.0} \\
\hline & $\begin{array}{|ll|}\% & \text { of } \\
\text { Total } & \\
\end{array}$ & 31.2 & 18.8 & 6.2 & 9.4 & 21.9 & 12.5 & 50.0 & \\
\hline \multirow{2}{*}{$\begin{array}{l}\text { Maximum } \\
\text { requirement }^{10}\end{array}$} & Count & 3 & 5 & 1 & 3 & 2 & 2 & 8 & \multirow[b]{2}{*}{100.0} \\
\hline & $\begin{array}{ll}\% & \text { of } \\
\text { Total } & \end{array}$ & 9.4 & 15.6 & 3.1 & 9.4 & 6.2 & 6.2 & 25.0 & \\
\hline \multirow[b]{2}{*}{ Total } & Count & 16 & 16 & 3 & 9 & 13 & 7 & 32 & \multirow[b]{2}{*}{100.0} \\
\hline & $\begin{array}{|ll|}\% & \text { of } \\
\text { Total } & \\
\end{array}$ & 50.0 & 50.0 & 9.4 & 28. & 40.6 & 21.9 & 100.0 & \\
\hline
\end{tabular}

Sources: Field survey, June 2014

$*$ No significant association $P=0.368$ (2-sided), **No significant association $P=0.794$ (2-sided)

Above table examines the relationship between researcher's evaluations of the educational facilities (Availability and condition of science laboratory) of selected schools. The data shows that more than 75 percent schools' sciences laboratory availability is poor condition and more than 25 percent schools have not available science laboratory. The result of this research shows around 75 percent of Nepalese schools' qualities of educational facilities are still unsatisfactory (Thapa, 2011). Similarly it can be generalized to Nepal as a whole.

Table: 4 Availability of computer in computer laboratory

\begin{tabular}{|c|c|c|c|c|c|c|c|c|c|}
\hline \multirow{2}{*}{\multicolumn{2}{|c|}{$\begin{array}{l}\text { Available of computers } \\
\text { in computer lab }\end{array}$}} & \multirow{2}{*}{\multicolumn{2}{|c|}{\begin{tabular}{|l|} 
Types of schools* \\
Community|Institutional
\end{tabular}}} & \multicolumn{4}{|c|}{ Ecological region** } & \multirow{2}{*}{\multicolumn{2}{|c|}{\begin{tabular}{|l|l|} 
Total & $\begin{array}{l}\text { Cumulative } \\
\text { Percent }\end{array}$ \\
\end{tabular}}} \\
\hline & & & & Mountain & Hill & Val & yTerai & & \\
\hline \multirow{2}{*}{ Not available } & Count & 2 & 1 & 0 & 1 & 1 & 1 & 3 & \multirow{2}{*}{-9.4} \\
\hline & Total \% & 6.2 & 3.1 & 0.0 & 3.1 & 3.1 & 3.1 & 9.4 & \\
\hline \multirow{2}{*}{ Less than 5} & Count & 2 & 2 & 0 & 1 & 2 & 1 & 4 & \multirow{2}{*}{21.9} \\
\hline & Total \% & 6.2 & 6.2 & 0.0 & 3.1 & 6.2 & 3.1 & 12.5 & \\
\hline \multirow{2}{*}{6 to 10} & Count & 0 & 1 & 0 & 0 & 1 & 0 & 1 & \multirow{2}{*}{-25.0} \\
\hline & Total \% & 0.0 & 3.1 & 0.0 & 0.0 & 3.1 & 0.0 & 3.1 & \\
\hline
\end{tabular}

\footnotetext{
${ }^{9}$ One combine science lab; all types of physics, chemistry and biology equipments are managed in the same room.

${ }^{10}$ Three sseparate science lab; The physics lab is equipped by optical, electrical; thermo dynamical, mechanical instruments, The chemistry lab is equipped with different types of solutions, salts and components and Biology lab is equipped by slides, microscopes, skeletons and different specimens.
} 
ISSN: 2362-1303 (Paper) | eISSN: 2362-1311(Online)

JOURNAL OF ADVANCED ACADEMIC RESEARCH (JAAR)

\begin{tabular}{|c|c|c|c|c|c|c|c|c|c|}
\hline \multirow{2}{*}{11 to 15} & Count & 1 & 3 & 1 & 1 & 2 & 0 & 4 & \multirow{2}{*}{37.5} \\
\hline & Total \% & 3.1 & 9.4 & 3.1 & 3.1 & 6.2 & 0.0 & 12.5 & \\
\hline \multirow{2}{*}{16 to 20} & Count & 6 & 0 & 0 & 3 & 2 & 1 & 6 & \multirow{2}{*}{56.3} \\
\hline & Total \% & 18.8 & 0.0 & 0.0 & 9.4 & 6.2 & 3.1 & 18.8 & \\
\hline \multirow{2}{*}{ More than 21} & Count & 5 & 9 & 2 & 3 & 5 & 4 & 14 & \multirow{2}{*}{100.0} \\
\hline & Total \% & 15.6 & 28.1 & 6.2 & 9.4 & 15.6 & 12.5 & 43.8 & \\
\hline \multirow{2}{*}{ Total } & Count & 16 & 16 & 3 & 9 & 13 & 7 & 32 & \multirow{2}{*}{100.0} \\
\hline & Total \% & 50.0 & 50.0 & 9.4 & 28.1 & 40.6 & 21.9 & 100.0 & \\
\hline
\end{tabular}

Sources: Field survey, June 2014

*No significant association $P=0.092$ (2-sided), **No significant association $P=0.952$ (2-sided)

The above table shows that there no signification association has been found between community and institutional schools and ecological wise schools' available of computers in computer lab. The data show that more than 75 percent schools' available of computers in computer lab is good condition and only 6.2 percent community schools and 3.1 percent institutional schools have not available computer lab.Most of the public schools they are left behind in terms of use of modern educational equipment such as use of computers as compared to private schools (Bhatta, 2005). Private schools spend much more on students' education besides other expenditures made on infrastructure and physical facilities as compared to public schools (Thapa, 2011). The study argues that private schools have managed such facilities better than those of public schools (SMAERC, 2008).

Table: 5 Achievement test min score

\begin{tabular}{|c|c|c|c|c|c|c|c|c|c|}
\hline \multirow{2}{*}{\multicolumn{2}{|c|}{$\begin{array}{l}\text { Achievement test } \\
\text { result percent }\end{array}$}} & \multicolumn{2}{|c|}{ Types of schools* } & \multicolumn{4}{|c|}{ Ecological region** } & \multirow[t]{2}{*}{ Total } & \multirow{2}{*}{$\begin{array}{l}\text { Cumulative } \\
\text { Percent }\end{array}$} \\
\hline & & Community & Institutional & Mountain & Hill & Valley & Terai & & \\
\hline \multirow{2}{*}{31 to 35} & Count & 2 & 0 & 0 & 1 & 0 & 1 & 2 & \multirow[b]{2}{*}{6.3} \\
\hline & Total \% & 6.2 & 0.0 & 0.0 & 3.1 & 0.0 & 3.1 & 6.2 & \\
\hline \multirow{2}{*}{36 to 40} & Count & 5 & 0 & 0 & 1 & 0 & 4 & 5 & \multirow[b]{2}{*}{21.9} \\
\hline & Total \% & 15.6 & 0.0 & 0.0 & 3.1 & 0.0 & 12.5 & 15.6 & \\
\hline \multirow{2}{*}{41 to 45} & Count & 7 & 0 & 2 & 4 & 1 & 0 & 7 & \multirow[b]{2}{*}{43.8} \\
\hline & Total \% & 21.9 & 0.0 & 6.2 & 12.5 & 3.1 & 0.0 & 21.9 & \\
\hline \multirow{2}{*}{46 to 50} & Count & 2 & 5 & 1 & 1 & 4 & 1 & 7 & \multirow[b]{2}{*}{65.6} \\
\hline & Total \% & 6.2 & 15.6 & 3.1 & 3.1 & 12.5 & 3.1 & 21.9 & \\
\hline \multirow{2}{*}{51 to 55} & Count & 0 & 11 & 0 & 2 & 8 & 1 & 11 & \multirow[b]{2}{*}{100.0} \\
\hline & Total \% & 0.0 & 34.4 & 0.0 & 6.2 & 25.0 & 3.1 & 34.4 & \\
\hline \multirow{2}{*}{ Total } & Count & 16 & 16 & 3 & 9 & 13 & 7 & 32 & \\
\hline & Total \% & 50.0 & 50.0 & 9.4 & 28.1 & 40.6 & 21.9 & 100.0 & \\
\hline
\end{tabular}

Sources: Field survey, June 2014 
ISSN: 2362-1303 (Paper) | eISSN: 2362-1311(Online)

JOURNAL OF ADVANCED ACADEMIC RESEARCH (JAAR)

*Significant association $P=0.000(2$-sided), ** Significant association $P=0.010$ (2-sided)

The above table shows that a significant associationhas been found between community and institutional and ecological wise schools students' achievement test min score. According to students' achievement in above table, wide range of students' from institutional school has got good result in comparison to the community based school. More than 40 percentage of community based school's students got below 45 marks achievement average score. Private schools' performances are still unsatisfactory (Thapa, 2011). Similarly it can be generalized to Nepal as a whole. Public schools are regularly suffering from low achievement, poor infrastructure and facilities and weak management and regulation. Studies have shown that in terms of students' cognitive development, public schools in Nepal have struggled to add value (Caddell, 2006; Carney, 2003). Governments' educational plans have continuously failed. Community schools are suffering from insufficient; admission, participation, retention of students, and educational quality (Carney,2003).

\section{Conclusion}

Following conclusion was sketched on the basic of above data:

- School's educational facilities give meaning to the teaching and learning process.

- School's management of educational facilities is an integral part of the overall management of the school.

- School's principal should carry out comprehensive assessment of the facilities to determine areas of their need.

- It requires an integrated effort of all stakeholders who possess the expertise needed for accurate and up-to-date assessment of all aspects of instructional facilities.

- The actualization of the goals and objectives of education require the available, most utilization and proper management of the facilities.

- Furthermore, advances in science and technology, require that the school management should adopt modern educational facilities management.

- Facilities provision and management will improve the quality of teaching and learning.

\section{Acknowledgement}

We would like to express my hearty gratitude to the all school principals and SMC members who helped me a lot to mirror the truth. We are further thankful to all of friends, who showed the way by encouraging and providing their constructive suggestions and comments to accomplish this article. We are also thankful to $\mathrm{PhD}$ Centre, Kathmandu, Nepal for the supportive role to wrap the research up. 
ISSN: 2362-1303 (Paper) | eISSN: 2362-1311(Online)

JOURNAL OF ADVANCED ACADEMIC RESEARCH (JAAR)

January 2015

\section{References}

Asiabaka, D. (. (2008, 4 8). The Need for Effective Facility Management in Schools in Nigeria. New York Science Journal, 1(2), 10-21. Retrieved Oct 10, 2014, from http://www.sciencepub.org

Daggett, W. R. (2008). Color in an Optimum Learning Environment. International Center fo Leadership in Education, Rexford, NY, 9.

Deepak Raj, P., \& Tapash, D. (2013). Performance of Community Schools in Nepal: A Macro Level Analysis. International Journal of Scientific \& Technology, 2(7), 148-152. Retrieved 2 15, 2015, from http://www.ijstr.org

GoN. (2010). National Framework of Child-friendly School For Quality Education. Department of Education. Kathmandu: Ministry of Education, Government of Nepal.

GoN. (2012). Flash I Report. Department of Education. Sanothimi, Bhaktapur: Ministry of Education, Government of Nepal.

GoN. (2014). Policies and Programmes of the Government of Nepal for Fiscal Year 2071-72 (2014-15). Rt. Hon. President, Dr. Ram Bsran Yadsv at the Meeting of the LegislatureParliament of the Constituent Assembly (pp. 1-15). Singh Durbar, Kathmandu: Government of Nepal Office of the Prime Minister and Council of Ministers. Retrieved 12 29, 2014, from http://www.opmcm,gov,np

Lawanson, O. A., \& Gede, N. T. (2011, November). Provision and Management of School Facilities for the Implementation of UBE Programme. Journal of Educational and Social Research, 1(4), 48. Retrieved Feb 5, 2013, from http://www.mcser.org/images/stories/JESR-Special-Issues/JESR-

November2011/lawanson-olukemi-anike.pdf

MOLJI. (2009). The Right of Children to Free and Compulsory Education Act. Legislative Department. New Delhi: The Gazette of India, Ministry of Law and Justice India. Retrieved 6 10, 2014, from http://ssa.nic.in/rte-docs/free\%20and\%20compulsory.pdf

Naresh, K., \& Paul, B. (2011). Library Development in Nepal: Problems and prospects. NLF presentain in Houston at NRN Conference (pp. 118-129). Houston Texas: Nepal Library Foundation. Retrieved Dec 10, 2014, from http://www.nepallibrary.org/NLFPresentation-in-Houston-at-NRN-Conference-2010

O'Sullivan, S. (2006). A Study of the Relationship between Building Conditions and Student Academic Achievement in Pennsylvania's High School. Virginia Polytechnic Institute and State University, Educational Leadership and Policy Studies. Falls Church, Virginia: 
ISSN: 2362-1303 (Paper) | eISSN: 2362-1311(Online)

JOURNAL OF ADVANCED ACADEMIC RESEARCH (JAAR)

Virginia Polytechnic Institute and State University. Retrieved Oct 1, 2013, from http://scholar.lib.vt.edu/theses/available/etd-08312006-

155402/unrestricted/SOSETD.pdf.pdf

OECD . (2013b). Innovative Learning Environments. paris: OECD Publishing .

OECD . (2013c). Effectiveness, Efficiency and Sufficiency: An OECD framework for a physical learning environments module. Paris: OECD Publishing. Retrieved 1 2, 2015, from http://www.oecd.org/edu/innovation-

education/centreforeffectivelearningenvironmentscele/LEEPFrameworkforWEB.docx

OLE Nepal. (2015 , 4 25). E-Pustakalaya. Retrieved from OLE Nepal.org: http://olenepal.org/wp-content/uploads/2012/01/inter-school-network.png

Propst, R. (1972). The High School: The Process and the Place. New York: Educational Facilities Laboratories. Retrieved Jan 1, 2014, from https://books.google.com.np/b

Thapa, A. (2011). Does private school competition improve public school performance? The case of Nepal. Graduate School of Art and Science. New York: Columbia University. Retrieved Dec 10, 2014, from http://academiccommons.columbia.edu/download/fedora_content/download/ac:132306/C ONTENT/Thapa_colu..

Timsina, T. P. (2008). School effectiveness with preference to the public and private schools in Nepal. School of Education. Dhulikheal: Kathmandu University.

Tribhuvan University. (2002). School Effectiveness in Nepal: A Synthesis of Indicators. Tribhuvan University, Department of Education. Kathmandu: Research Centre for Educational Innovation and Development (CERID). 